Cite this: Energy Environ. Sci., 2013, 6, 2646

Received 1st March 2013

Accepted 18th June 2013

DOI: $10.1039 / c 3 e e 40712 \mathrm{~h}$

www.rsc.org/ees

\section{Photoelectrochemical oxidation of anions by $\mathrm{WO}_{3}$ in aqueous and nonaqueous electrolytes $\uparrow$}

\begin{abstract}
Qixi Mi, Robert H. Coridan, Bruce S. Brunschwig, Harry B. Gray* and Nathan S. Lewis*
The behavior of $\mathrm{WO}_{3}$ photoanodes has been investigated in contact with a combination of four anions $\left(\mathrm{Cl}^{-}, \mathrm{CH}_{3} \mathrm{SO}_{3}{ }^{-}, \mathrm{HSO}_{4}{ }^{-}\right.$, and $\left.\mathrm{ClO}_{4}{ }^{-}\right)$and three solvents (water, acetonitrile, and propylene carbonate), to elucidate the role of the semiconductor surface, the electrolyte, and redox kinetics on the current density vs. potential properties of n-type $\mathrm{WO}_{3}$. In $1.0 \mathrm{M}$ aqueous strong acids, although the flat-band potential $\left(E_{\mathrm{fb}}\right)$ of $\mathrm{WO}_{3}$ was dominated by electrochemical intercalation of protons into $\mathrm{WO}_{3}$, the nature of the electrolyte influenced the onset potential $\left(E_{\mathrm{on}}\right)$ of the anodic photocurrent. In aprotic solvents, the electrolyte anion shifted both $E_{\mathrm{fb}}$ and $E_{\mathrm{on}}$, but did not significantly alter the overall profile of the voltammetric data. For $0.50 \mathrm{M}$ tetra( $n$-butyl)ammonium perchlorate in propylene carbonate, the internal quantum yield exceeded unity at excitation wavelengths of $300-390 \mathrm{~nm}$, indicative of current doubling. A regenerative photoelectrochemical cell based on the reversible redox couple $\mathrm{B}_{10} \mathrm{Br}_{10}{ }^{-12-}$ in acetonitrile, with a solution potential of $\sim 1.7 \mathrm{~V}$ vs. the normal hydrogen electrode, exhibited an opencircuit photovoltage of $1.32 \mathrm{~V}$ under $100 \mathrm{~mW} \mathrm{~cm}^{-2}$ of simulated Air Mass $1.5 \mathrm{global}$ illumination.
\end{abstract}

\title{
Broader context
}

Electrolytes are an indispensable constituent in (photo)electrochemistry for forming interfacial double layers and conducting currents. Nonetheless, it is generally considered that the role of electrolytes in (photo)electrochemistry is merely supporting and implicit, because the identity and concentration of electrolytes do not directly determine the electrode potentials and current densities. Results from this work suggest that when in contact with various aqueous and nonaqueous solutions and under simulated solar illumination, thin-film $\mathrm{WO}_{3}$ photoanodes oxidized primarily the electrolyte anions in spite of the dominant molarity of the solvent in the electrolyte solutions. The priority of anion oxidation has been utilized to construct nonaqueous, regenerative photoelectrochemical cells that produce large open-circuit voltages. In addition to $\mathrm{O}_{2}(\mathrm{~g})$ evolution from water, such electrolyte effects can result in undesired side reactions, and such processes should be taken into account when $\mathrm{WO}_{3}$ photoanodes are incorporated into multi-component devices for solar-driven water splitting.

\section{Introduction}

$\mathrm{WO}_{3}$ is an interesting photoanode material for use in earlygeneration tandem-type light absorber systems for solar-driven water splitting. In contact with aqueous solutions, photogenerated holes in the valence band of $\mathrm{WO}_{3}$, at an electrochemical potential of $\sim 3.0 \mathrm{~V} v s$. the normal hydrogen electrode (NHE), are sufficiently oxidizing to produce free or surfaceattached hydroxyl radicals $(\mathrm{OH})$ that can eventually lead to $\mathrm{O}_{2}(\mathrm{~g})$. This widely accepted reaction scheme has inspired increasing interest ${ }^{1-10}$ in $\mathrm{WO}_{3}$ photoanodes, both pristine and decorated with oxygen-evolving catalysts.

Several studies ${ }^{11-14}$ of the photoelectrochemical behavior of $\mathrm{WO}_{3}$ in aqueous electrolytes have recently suggested that an

Beckman Institute and Kavli Nanoscience Institute, Division of Chemistry and Chemical Engineering, California Institute of Technology, M/C 127-72, 1200 E. California Blvd., Pasadena, CA 91125, USA. E-mail: hbgray@caltech.edu; nslewis@caltech.edu

$\dagger$ Electronic supplementary information (ESI) available. See DOI: $10.1039 / \mathrm{c} 3 \mathrm{ee} 40712 \mathrm{~h}$ alternative process, in which oxidation of electrolyte anions, such as $\mathrm{Cl}^{-}, \mathrm{HSO}_{4}{ }^{-}$, and $\mathrm{ClO}_{4}{ }^{-}$, effectively competes with oxidation of water at the $\mathrm{WO}_{3} /$ electrolyte interface, dominates the photoanodic behavior of n-type $\mathrm{WO}_{3}$ especially under acidic conditions. Although some of the oxidation products $\left(\mathrm{Cl}_{2}\right.$ and $\left.\mathrm{S}_{2} \mathrm{O}_{8}{ }^{2-}\right)$ have been confirmed experimentally, ${ }^{11-13}$ the importance of the oxidation of water to produce $\mathrm{OH}^{-}$as an energetic intermediate, relative to the oxidation of electrolyte anions, has yet to be fully elucidated. ${ }^{14}$ In aqueous media, the overwhelming molarity of water $(>50 \mathrm{M})$ that hydrates and protonates the $\mathrm{WO}_{3}$ surface makes disentangling these effects difficult. In contrast, valuable information can in principle be obtained by photoelectrochemical investigations of the same series of anions in nonaqueous electrolytes. Compared with main-group semiconductors such as $\mathrm{Si}^{15}$ and $\mathrm{GaP},{ }^{16}$ the photoelectrochemistry of metal oxides in nonaqueous solvents is not well elaborated. Early work regarding $\mathrm{n}$-type $\mathrm{TiO}_{2}{ }^{17}$ and $\mathrm{ZnO}^{18}$ electrodes in acetonitrile solutions placed emphasis on the behavior of the conduction-band electrons in these semiconductors. 
Nonaqueous electrolytes can also overcome the restriction on the available operational electrochemical potential window that is associated with operation in aqueous media. The flatband potential $\left(E_{\mathrm{fb}}\right)$ of n-type $\mathrm{WO}_{3}$, at $\sim 0.4 \mathrm{~V} v s$. $\mathrm{NHE},{ }^{19,20}$ is too positive to effect the reduction of protons with no external bias applied to the system. Given the standard electrode potential for water oxidation, $E^{0}=1.23 \mathrm{~V} v s$. $\mathrm{NHE}, \mathrm{WO}_{3}$ photoanodes can therefore in theory generate an open-circuit voltage $\left(V_{\mathrm{oc}}\right)$ of at most $\sim 0.8 \mathrm{~V}$ for water oxidation. Hence, much of the band gap energy of $\mathrm{WO}_{3}\left(\boldsymbol{E}_{\mathrm{g}}=2.6 \mathrm{eV}\right)^{21}$ is not used electrochemically, and a substantial bias voltage from the photocathode is required to achieve overall water splitting. In nonaqueous electrolytes, existing knowledge about Si photoelectrodes ${ }^{22,23}$ predicts that both the $E_{\mathrm{fb}}$ of $\mathrm{WO}_{3}$ and the Nernstian potential of the solution are tunable beyond these limits. To maximize the $V_{\text {oc }}$ of regenerative photoelectrochemical cells, a nonaqueous redox system with a very positive Nernstian potential (e.g., $>1.5 \mathrm{~V} v s$. NHE) therefore needs to be identified.

We describe herein the nonaqueous photoelectrochemistry of $\mathrm{WO}_{3}$, and report the voltammetric, spectral response, and electrochemical impedance data obtained by using a combination of four anions $\left(\mathrm{Cl}^{-}, \mathrm{CH}_{3} \mathrm{SO}_{3}{ }^{-}, \mathrm{HSO}_{4}{ }^{-}\right.$, and $\left.\mathrm{ClO}_{4}{ }^{-}\right)$and three solvents (water, acetonitrile, and propylene carbonate). Furthermore, a regenerative photoelectrochemical cell has been constructed by use of a reversible redox couple, $\mathrm{B}_{10} \mathrm{Br}_{10}{ }^{-/ 2-}$, that has a very positive formal reduction potential. The resulting $\mathrm{WO}_{3}$-based solid/liquid contact produced an open-circuit photovoltage of $1.32 \mathrm{~V}$. Thus, the use of aprotic solvents and reversible redox couples aids in disentangling the contributions from the semiconductor surface, the electrolyte, and redox kinetics to the photoanodic behavior of $\mathrm{WO}_{3}$, and also opens a new venue for understanding other semiconducting metal oxides as photoanode materials.

\section{Experimental}

\section{Chemicals}

Sodium tungstate dihydrate $\left(\mathrm{Na}_{2} \mathrm{WO}_{4} \cdot 2 \mathrm{H}_{2} \mathrm{O}\right.$, Aldrich 223336, 99\%), tungsten foil (Alfa Aesar 10417, 99.95\%), 1.0 M hydrochloric acid (J. T. Baker 5620), acetonitrile (ACN, J. T. Baker 9035-10, ultra low water), propylene carbonate (PC, Aldrich 310328 , anhydrous, 99.7\%), tetra(n-butyl)ammonium chloride (TBACl, TCI America T0055, >98\%), tetra( $n$-butyl)ammonium bisulfate $\left(\mathrm{TBAHSO}_{4}\right.$, Aldrich $86868, \geq 99 \%$ ), and tetra(n-butyl) ammonium perchlorate $\left(\mathrm{TBAClO}_{4}\right.$, Fluka 86893, $\geq 99 \%$ ) were used as received. Concentrated sulfuric acid (J. T. Baker 9681, 98\%), methanesulfonic acid (Aldrich 471356, $\geq 99.5 \%$ ), and perchloric acid (Fisher A2286, 60\%) were diluted to $1.0 \mathrm{M}$ using deionized water (18 $\mathrm{M} \Omega \mathrm{cm}$ resistivity) obtained from a Barnstead Nanopure system. All other chemicals were ACS reagents or were greater than $98 \%$ purity.

Tetra(n-butyl)ammonium methanesulfonate $\left(\mathrm{TBASO}_{3} \mathrm{CH}_{3}\right.$, Fluka $86877, \geq 97 \%$ ) was recrystallized from toluene. Bis(methanesulfonyl) peroxide $\left[\left(\mathrm{CH}_{3} \mathrm{SO}_{3}\right)_{2}\right]$ was synthesized ${ }^{24}$ electrochemically as a white solid from a neat solution of sodium methanesulfonate in methanesulfonic acid. Bis[tetra( $n$-butyl) ammonium] decabromo-closo-decaborate(2-) $\left(\mathrm{TBA}_{2} \mathrm{~B}_{10} \mathrm{Br}_{10}\right)$ was prepared in two steps ${ }^{25,26}$ using decaborane (Alfa Aesar 87892, $98 \%)$, bromine, and tetra( $n$-butyl)ammonium bromide, and was subsequently recrystallized from acetone/ethanol as colorless needles. $\mathrm{TBA}_{2} \mathrm{~B}_{10} \mathrm{Br}_{10}$ is not hygroscopic and is readily soluble in aprotic organic solvents.

\section{Electrochemistry}

Electrochemical measurements were performed in a standard three-electrode configuration, in which a Pt-mesh counter electrode was isolated from the electrolyte by a medium glass frit, and the reference electrode was isolated from the electrolyte by a Luggin capillary. Voltammetric data were collected at a scan rate of $50 \mathrm{mV} \mathrm{s}^{-1}$ using a BAS 100B electrochemical analyzer. The reference electrode for measurements in aqueous electrolytes was a $\mathrm{Ag} / \mathrm{AgCl} / 3.0 \mathrm{M} \mathrm{NaCl}$ electrode (Bioanalytical Systems, Inc.), which was taken to have a potential of $E=0.209 \mathrm{~V}$ vs. the normal hydrogen electrode (NHE). Nonaqueous reference electrodes were assembled from a AgClcoated Ag wire, a filling solution, and a glass tube that had a Vycor frit at its tip. ${ }^{27}$ The filling solution was saturated tetramethylammonium chloride (TMACl) in ACN, or saturated $\mathrm{LiCl}$ in $\mathrm{PC}^{28}$ The formal potential of the ferrocenium/ferrocene redox couple $\left(E^{0 \prime}\left(\mathrm{Fc}^{+/ 0}\right)\right)$ vs. a nonaqueous reference electrode was measured by performing cyclic voltammetry and differential pulse voltammetry on a polished Pt-disc working electrode in $0.1 \mathrm{M} \mathrm{TBAClO}_{4}$ in the corresponding solvent. Comparison with the known values ${ }^{29}$ of $E^{0 \prime}\left(\mathrm{Fc}^{+/ 0}\right) v s$. NHE in each solvent gave the potentials of these nonaqueous reference electrodes: $E(\mathrm{Ag} / \mathrm{AgCl} / \mathrm{sat}$. TMACl, $\mathrm{ACN})=0.06 \mathrm{~V}$ vs. NHE, and $E(\mathrm{Ag} / \mathrm{AgCl} /$ sat. $\mathrm{LiCl}, \mathrm{PC})=0.07 \mathrm{~V} v$ s. NHE. All potentials measured in $\mathrm{H}_{2} \mathrm{O}$, $\mathrm{ACN}$, or PC relative to the respective reference electrode were converted to values $v s$. NHE and the resulting potentials are reported herein.

\section{$\mathrm{WO}_{3}$ photoanodes}

To form working electrodes, samples of $\mathrm{SnO}_{2}$ :F-coated glass slides (FTO, Hartford Glass, TEC 15) and $\mathrm{W}$ foil were cut into pieces that were $1.0 \mathrm{~cm}$ in width. After immersing the slides for $30 \mathrm{~min}$ in a modified piranha solution $\left(1.0 \mathrm{~g}\left(\mathrm{NH}_{4}\right)_{2} \mathrm{~S}_{2} \mathrm{O}_{8}\right.$ in $20 \mathrm{~mL}$ concentrated $\mathrm{H}_{2} \mathrm{SO}_{4}$ ), the substrates were rinsed with $\mathrm{H}_{2} \mathrm{O}$ and then with ethanol, to create a clean, hydrophilic surface that adhered well to the $\mathrm{WO}_{3}$ overlayer. A column (Sigma C4169, $\varnothing 1.5 \mathrm{~cm} \times 10 \mathrm{~cm}$ ) packed with strongly acidic ion-exchange resin (Fisher Rexyn $101(\mathrm{H}), 1.9 \mathrm{mEq} . \mathrm{mL}^{-1}$ ) was washed with deionized water until the $\mathrm{pH}$ value of the washings was $\sim 4$. The column was then loaded with $0.566 \mathrm{~mL}(0.5 \mathrm{mmol})$ of $3 \% \mathrm{H}_{2} \mathrm{O}_{2}$ and a solution of $0.330 \mathrm{~g}(1.00 \mathrm{mmol}) \mathrm{Na}_{2} \mathrm{WO}_{4} \cdot 2 \mathrm{H}_{2} \mathrm{O}$ in $1.50 \mathrm{~mL}$ water, and was subsequently eluted with $20 \mathrm{~mL}$ of deionized water. The eluate was a clear, pale yellow solution of peroxytungstic acid, and was immediately consumed in the next step. Peroxide test strips (EM Quant 10081-1) indicated that the free $\mathrm{H}_{2} \mathrm{O}_{2}$ concentration was $10-30 \mathrm{ppm}$ in this solution.

A cleaned electrode substrate (FTO glass or W foil) was electrically connected to a Cu clamp, and was immersed in the peroxytungstic acid to a depth of $1.0 \mathrm{~cm}$. The cathodic electrodeposition of $\mathrm{WO}_{3}$ was performed, without stirring, at $-0.29 \mathrm{~V}$ 
vs. NHE, with the passage of $-0.25 \mathrm{C} \mathrm{cm}^{-2}$ of charge density (at a current density of $\sim-0.4 \mathrm{~mA} \mathrm{~cm}{ }^{-2}$ ) yielding a blue layer of reduced $\mathrm{WO}_{3} \cdot x \mathrm{H}_{2} \mathrm{O}$ on the working electrode surface, as well as $\mathrm{O}_{2}$ bubbles at the Pt counter electrode. The working electrode was removed from the bath, rinsed with water, dried in air, and baked at $225{ }^{\circ} \mathrm{C}$ until the blue color had faded completely, typically requiring $\sim 10 \mathrm{~min}$ of baking time. The depositiondehydration cycle was then repeated. After 5-6 cycles, the electrode was annealed at $500{ }^{\circ} \mathrm{C}$ in air for $1 \mathrm{~h}$, yielding a pale yellow film of $\mathrm{WO}_{3}$. The mass and thickness of the electrodeposited $\mathrm{WO}_{3}$ film were determined using a Sartorius CPA225D semi-micro balance and a Dektak XT profilometer, respectively. Unsealed with epoxy, $\mathrm{WO}_{3} / \mathrm{FTO}$ electrodes were heated at $225{ }^{\circ} \mathrm{C}$ for $10 \mathrm{~min}$ before each new experiment. The $\mathrm{WO}_{3} / \mathrm{W}$ electrode was electrically connected to a $\mathrm{Cu}$ wire, and was sealed with epoxy resin (Loctite Hysol 9460) completely on one side and partially on the other side to expose $\sim 1.0 \mathrm{~cm}^{2}$ of $\mathrm{WO}_{3}$ but no bare $\mathrm{W}$.

\section{Photoelectrochemistry}

Voltammetric current density $v s$. potential $(J-E)$ data $\left(50 \mathrm{mV} \mathrm{s}^{-1}\right)$ were collected using a BAS 100B electrochemical analyzer and a solar simulator, in conjunction with a photoelectrochemical cell that has been described previously. ${ }^{12}$ Illumination was provided by an Oriel solar simulator equipped with an Air Mass 1.5 global (AM 1.5G) filter. The light intensity was adjusted at the sample plane to provide the same open-circuit voltage on a secondary standard (a Solarex Si photodiode) as that produced by illumination of the photodiode with $100 \mathrm{~mW} \mathrm{~cm}^{-2}$ of AM 1.5G illumination. The electrolyte produced a $1.2 \mathrm{~cm}$ optical path length between the optical window and the working electrode. A miniature cell was fabricated similarly from a $10 \mathrm{~mL}$ round bottom flask, whose single neck provided access for all of the electrodes. The error in the values of the photocurrent density $(J)$ was estimated to be $\pm 10 \%$.

Spectral response measurements were performed using ultraviolet and visible light produced by a $150 \mathrm{~W}$ Xe arc lamp. The light was chopped at $1.0 \mathrm{~Hz}$, and was passed through a monochromator that had slits $0.5 \mathrm{~mm}$ in width. Either the photoelectrochemical cell or a calibrated Si photodiode (OSI Optoelectronics, UV-50) was positioned in the light path, and the illuminated spot was focused to $\sim 1 \times 1 \mathrm{~mm}^{2}$ at the front surface of the working electrode. At a fixed potential, the wavelength of the incident light was varied in $10 \mathrm{~nm}$ steps, and the resulting photocurrents were measured with lock-in detection using a Gamry Series G 300 potentiostat. The external quantum yield $\left(\Phi_{\text {ext }}\right)$ of the photoelectrochemical cell was calculated based on the known $\Phi_{\text {ext }}$ values of the calibrated $\mathrm{Si}$ diode. To compensate for fluctuations in the intensity of the monochromatic illumination, a small fraction of the light beam was split using a quartz plate and was continuously monitored by another Si photodiode.

\section{Electrochemical impedance spectroscopy (EIS)}

EIS was performed in the absence of illumination on a PARSTAT 2273 potentiostat/frequency response analyzer using the
PowerSUITE software. To allow for equilibration between the $\mathrm{WO}_{3}$ film and the nonaqueous electrolytes, prior to each impedance measurement five voltammetric cycles were run under illumination over the same potential range as used for collecting the impedance data. For each modulation frequency between $20 \mathrm{mHz}$ and $2.0 \mathrm{MHz}$ (four frequency values per decade), the reactance of a $\mathrm{WO}_{3} / \mathrm{FTO}$ electrode was measured over a potential range of $1.6 \mathrm{~V}$ in the aqueous electrolytes and of $2.3 \mathrm{~V}$ in the nonaqueous electrolytes, in parallel with the potential ranges of the corresponding voltammetric scans. The EIS dataset thus obtained was fitted using MATLAB to produce Mott-Schottky plots and additionally to extract $E_{\mathrm{fb}}$ values from the resulting data.

\section{Spectrophotometry and microscopy}

The absorption spectra of electrolytes were measured in a $1 \mathrm{~cm}$ quartz cuvette using an Agilent 8453 UV-visible spectrophotometer. The diffuse reflectance spectrum of the $\mathrm{WO}_{3} /$ FTO photoanode was taken on a Cary 5000 UV-visible spectrophotometer by placing the photoanode in the center of an integrating sphere. Field-emission scanning electron microscopy (FESEM) was performed on a Zeiss model 1550VP.

\section{Results}

\section{$\mathrm{WO}_{3} / \mathrm{FTO}$ and $\mathrm{WO}_{3} / \mathrm{W}$ photoanodes}

$\mathrm{WO}_{3}$ films on FTO-coated glass or $\mathrm{W}$ foil were fabricated by cathodic electrodeposition from peroxytungstic acid and subsequent annealing in air. Fig. S1 (ESI $\dagger$ ) shows that these two types of $\mathrm{WO}_{3}$ films possessed similar surface morphology with crystallites $\sim 50 \mathrm{~nm}$ in size and crevices between the crystallites. The porosity of the $\mathrm{WO}_{3}$ films that were electrodeposited on FTO-coated glass was calculated to be $22 \%$, based on the measured dimension $\left(1.6 \pm 0.1 \mu \mathrm{m} \times 1.0 \mathrm{~cm}^{2}\right)$ and mass $(0.90 \pm 0.02 \mathrm{mg})$ of the $\mathrm{WO}_{3}$ films, in addition to the density $\left(7.2 \mathrm{~g} \mathrm{~cm}^{-3}\right)$ of crystalline $\mathrm{WO}_{3} \cdot{ }^{13}$ During annealing, the surface of the $\mathrm{W}$ foil developed a thin oxide layer so the mass of the electrodeposited $\mathrm{WO}_{3}$ on $\mathrm{W}$ could not be directly determined by the mass gain of the W substrate. Fig. S2 (ESI $\dagger$ ) shows the cyclic voltammetric data acquired from these electrodes in $1.0 \mathrm{M}$ $\mathrm{HCl}(\mathrm{aq})$ under room light, referred to as "dark". For the $\mathrm{WO}_{3} / \mathrm{FTO}$ electrode, the anodic current showed an onset at $E=\sim 1.6 \mathrm{~V}$ vs. NHE. The current density was largely uniform across the film area, as probed using a pipette that was filled with $1.0 \mathrm{M} \mathrm{HCl}(\mathrm{aq})$ and that contacted $\sim 0.01 \mathrm{~cm}^{2}$ of the $\mathrm{WO}_{3}$ surface. For the $\mathrm{WO}_{3} / \mathrm{W}$ electrode, the anodic current originated only from the edges of the $\mathrm{W}$ foil. After sealing the back and edges of the electrode with epoxy resin, no significant faradaic current was observed in the dark at $E=0.6-2.2 \mathrm{~V} v s$. NHE.

\section{Photoelectrochemical oxidation of anions}

Photoelectrochemical experiments were performed on a $\mathrm{WO}_{3} /$ FTO electrode in one of three different solvents (water, ACN, and PC) that each contained one of four anions $\left(\mathrm{Cl}^{-}, \mathrm{CH}_{3} \mathrm{SO}_{3}{ }^{-}\right.$, $\mathrm{HSO}_{4}{ }^{-}$, and $\mathrm{ClO}_{4}{ }^{-}$). Fig. 1 displays the $J-E$ characteristics of a $\mathrm{WO}_{3} / \mathrm{FTO}$ electrode in contact with these electrolytes, with the 

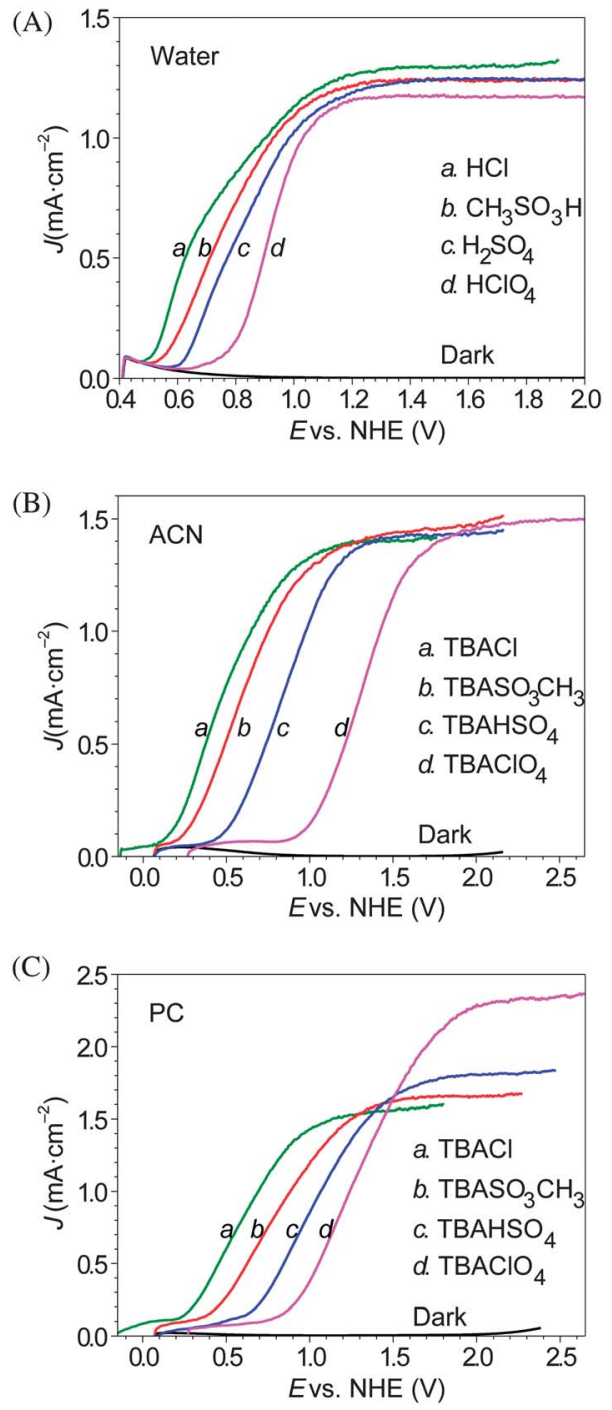

Fig. 1 Voltammograms of a $\mathrm{WO}_{3} /$ FTO photoanode in (A) water, (B) ACN, and (C) $\mathrm{PC}$ that contained $\mathrm{Cl}^{-}$(green), $\mathrm{CH}_{3} \mathrm{SO}_{3}{ }^{-}$(red), $\mathrm{HSO}_{4}{ }^{-}$(blue), or $\mathrm{ClO}_{4}{ }^{-}$(magenta), under simulated sunlight (AM $1.5 \mathrm{G}$ illumination, $100 \mathrm{~mW} \mathrm{~cm}^{-2}$ ). The electrolytes were $1.0 \mathrm{M}$ acids in water and $0.50 \mathrm{M}$ tetra( $n$-butyl)ammonium salts in $\mathrm{ACN}$ or PC. All panels also depict the results from control experiments with $\mathrm{HSO}_{4}{ }^{-}$in the dark (black).

aqueous electrolytes containing $1.0 \mathrm{M}$ acid and the nonaqueous ACN or PC electrolytes containing $0.50 \mathrm{M}$ of the appropriate tetra(n-butyl)ammonium salt. The dark current densities were $<0.05 \mathrm{~mA} \mathrm{~cm}^{-2}$ at $E=0.6-1.9 \mathrm{~V} v s$. NHE. In contact with the aqueous acids, capacitive current densities were observed in the dark for $E<0.6 \mathrm{~V} v s$. NHE. The $\mathrm{WO}_{3}$ film turned blue at $E<0.2 \mathrm{~V}$ $v s$. NHE, and fragmented and delaminated at more negative potentials. In ACN or PC, no color change of $\mathrm{WO}_{3}$ was observed at $E=-0.1 \mathrm{~V} v s$. NHE.

The onset potential of the photocurrent $\left(E_{\text {on }}\right)$ was a function of the electrolyte anion, following the order $E_{\text {on }}\left(\mathrm{Cl}^{-}\right)<E_{\text {on }}\left(\mathrm{CH}_{3} \mathrm{SO}_{3}{ }^{-}\right)$ $<E_{\text {on }}\left(\mathrm{HSO}_{4}{ }^{-}\right)<E_{\text {on }}\left(\mathrm{ClO}_{4}{ }^{-}\right)$. The photocurrent densities rose steadily for $E>E_{\text {on }}$, and in water and ACN eventually reached a plateau value $\left(J_{\mathrm{ph}}\right)$ that was insensitive to the electrolyte. In PC, however, the $J_{\mathrm{ph}}$ value increased from $1.5 \mathrm{~mA} \mathrm{~cm}{ }^{-2}$ for the TBACl electrolyte to $2.3 \mathrm{~mA} \mathrm{~cm}^{-2}$ for $\mathrm{TBAClO}_{4}$, and exhibited intermediate values for the other electrolytes. When passing a photocurrent density of $J_{\mathrm{ph}}$, the $\mathrm{WO}_{3}$ surfaces exhibited no observable gas bubbles or color change. At the Pt counter electrode, a gas, presumably $\mathrm{H}_{2}$ from the following cathode reactions, was evolved from electrolytes containing $\mathrm{TBAHSO}_{4}$ or PC:

$$
\begin{gathered}
\mathrm{HSO}_{4}{ }^{-}+\mathrm{e}^{-}(\mathrm{Pt}) \rightarrow \mathrm{SO}_{4}{ }^{2-}+1 / 2 \mathrm{H}_{2} \uparrow \\
\left(\mathrm{CH}_{3} \mathrm{CH}_{2} \mathrm{CH}_{2} \mathrm{CH}_{2}\right)_{4} \mathrm{~N}^{+}+\mathrm{e}^{-}(\mathrm{Pt}) \rightarrow \\
\left(\mathrm{CH}_{3} \mathrm{CH}_{2} \mathrm{CH}_{2} \mathrm{CH}_{2}\right)_{3} \mathrm{~N}+\mathrm{CH}_{3} \mathrm{CH}_{2} \mathrm{CH}=\mathrm{CH}_{2}+1 / 2 \mathrm{H}_{2} \uparrow \text { (ref. 30) }
\end{gathered}
$$

For TBACl, $\mathrm{TBASO}_{3} \mathrm{CH}_{3}$, or $\mathrm{TBAClO}_{4}$ in $\mathrm{ACN}$, the electrolyte in the cathode chamber turned yellow, which could be due to a reductive condensation reaction involving acetonitrile. The $J-E$ behavior of the $\mathrm{WO}_{3} / \mathrm{W}$ photoanode resembled that of the $\mathrm{WO}_{3}$ /FTO photoanode, but the former produced $\sim 10 \%$ less photocurrent density than the latter under the same conditions.

\section{Spectral response}

The external quantum yield $\left(\Phi_{\text {ext }}\right)$ of the $\mathrm{WO}_{3} /$ FTO photoanode was measured at fixed electrode potentials in the plateau region of the $J-E$ data shown in Fig. 1. For example, Fig. S3 (ESI $\dagger$ ) shows the results obtained at $1.7 \mathrm{~V} v s$. NHE for $1.0 \mathrm{M} \mathrm{HClO}_{4}$ in water, and at $2.4 \mathrm{~V}$ vs. NHE for $0.50 \mathrm{M} \mathrm{TBAClO}_{4}$ in $\mathrm{ACN}$ or PC. The diffuse reflectance data for the $\mathrm{WO}_{3} / \mathrm{FTO}$ photoanode $\left(R_{\text {electrode }}\right)$ and the transmittance of the electrolyte between the light source and the $\mathrm{WO}_{3}\left(T_{\text {electrolyte}}\right)$, both presented in Fig. S4 (ESI $\dagger$ ), were used to convert the $\Phi_{\text {ext }}$ values to internal quantum yields $\left(\Phi_{\text {int }}\right)$ :

$$
\Phi_{\text {int }}=\Phi_{\text {ext }} / T_{\text {electrolyte }} /\left(1-R_{\text {electrode }}\right)
$$

For the electrolytes in water or ACN, the values of $T_{\text {electrolyte }}$ were essentially unity at wavelengths $\geq 300 \mathrm{~nm}$. Fig. 2 shows a plot of $\Phi_{\text {int }} v s$. wavelength for the $\mathrm{WO}_{3} /$ FTO photoanode in contact with electrolytes that contained $\mathrm{ClO}_{4}{ }^{-}$. The spectral response displayed similar profiles for all three solvents, with $\Phi_{\text {int }}$ maximizing at 350-360 $\mathrm{nm}$ and approaching zero at $\geq 480 \mathrm{~nm}$, the latter coincident with the optical band gap of $\mathrm{WO}_{3}$ at $2.6 \mathrm{eV} .^{21}$ However, the solvent had an impact on the magnitude of $\Phi_{\text {int }}$, which at 300-390 nm exceeded unity in PC, but was only $\sim 0.5$ in

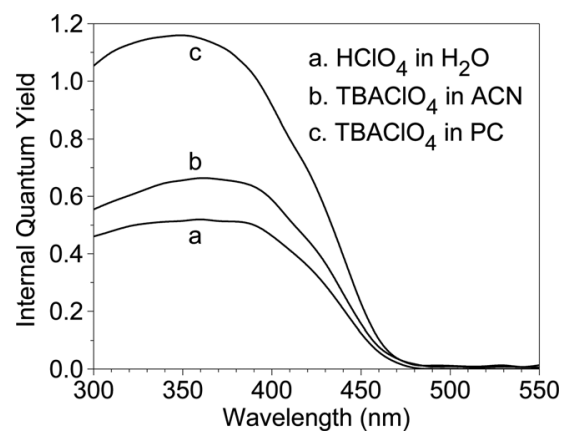

Fig. 2 Internal quantum yields $\left(\Phi_{\text {int }}\right)$ calculated according to eqn (1), for a $\mathrm{WO}_{3}$ /FTO photoanode in contact with electrolytes that contained $\mathrm{ClO}_{4}{ }^{-}$. 
Table 1 Maximum values of the internal quantum yield $\left(\Phi_{\text {int }}\right)$ of a $\mathrm{WO}_{3} /$ FTO photoanode in contact with various solvents and electrolytes, under the same conditions as in Fig. 1

\begin{tabular}{lllll}
\hline & $\mathrm{Cl}^{-}$ & $\mathrm{CH}_{3} \mathrm{SO}_{3}{ }^{-}$ & $\mathrm{HSO}_{4}{ }^{-}$ & $\mathrm{ClO}_{4}{ }^{-}$ \\
\hline Water & 0.57 & 0.56 & 0.55 & 0.53 \\
ACN & 0.63 & 0.65 & 0.63 & 0.66 \\
PC & 0.69 & 0.79 & 0.87 & 1.15 \\
\hline
\end{tabular}

water. Table 1 summarizes the maxima of $\Phi_{\text {int }}$ for $\mathrm{WO}_{3}$ in all solvent-electrolyte combinations investigated in this work.

\section{Electrochemical impedance spectroscopy}

Fig. S5 (ESI $\dagger$ ) shows representative Bode plots of the EIS data for a polycrystalline $\mathrm{WO}_{3} /$ FTO photoanode in contact with various electrolyte-solvent combinations. In the frequency range of $\sim 1$

(A)

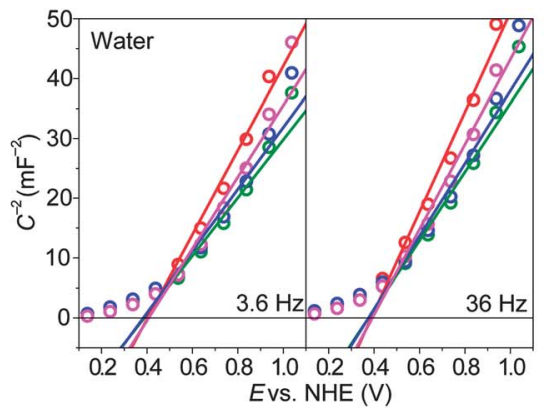

(B)

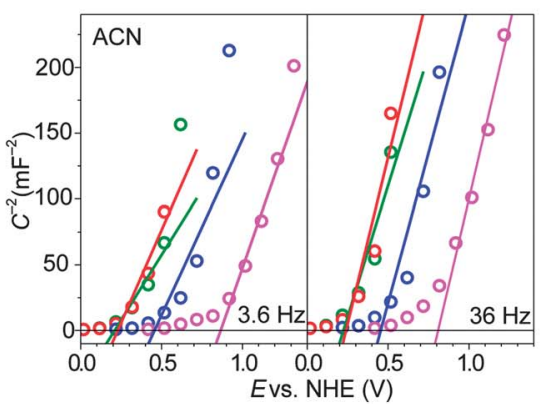

(C)

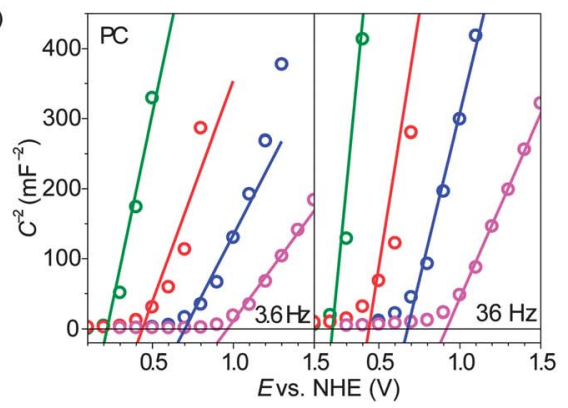

Fig. 3 Mott-Schottky plots of the differential capacitance (C) vs. potential (E) of a $\mathrm{WO}_{3} / \mathrm{FTO}$ photoanode in (A) water, (B) $\mathrm{ACN}$, and (C) PC that contained $\mathrm{Cl}^{-}$ (green), $\mathrm{CH}_{3} \mathrm{SO}_{3}{ }^{-}$(red), $\mathrm{HSO}_{4}{ }^{-}$(blue), or $\mathrm{ClO}_{4}{ }^{-}$(magenta), each measured at two modulation frequencies in the dark immediately after five corresponding $J-E$ scans in Fig. 1 were performed. Other conditions were identical to those in Fig. 1. Values of flat-band potential $\left(E_{\mathrm{fb}}\right)$ were estimated by linear extrapolation (solid lines) of the experimental data (open circles). to $50 \mathrm{~Hz}$, the measured impedance data were in the capacitive regime, and the differential capacitance $(C)$ was extracted at each potential $(E)$ of the $\mathrm{WO}_{3} /$ FTO photoanode. Fig. 3 presents Mott-Schottky plots of $C^{-2}$ vs. $E$, and Tables S1 and S2† list the values of $E_{\mathrm{fb}}$ and of the dopant density $\left(N_{\mathrm{D}}\right)$, respectively, obtained by the linear fits depicted in Fig. 3. In 1.0 $\mathrm{M}$ aqueous strong acids, these plots (Fig. 3A) displayed little dependence on the electrolyte anion at frequencies from $0.3 \mathrm{~Hz}$ to at least $0.3 \mathrm{kHz}$. In contrast, the Mott-Schottky plots for $\mathrm{WO}_{3}$ in ACN (Fig. 3B) or in PC (Fig. 3C) were strongly affected by the electrolyte anion. The relative order of the $E_{\mathrm{fb}}$ values with different electrolytes, from more negative to more positive, was $E_{\mathrm{fb}}\left(\mathrm{Cl}^{-}\right) \approx E_{\mathrm{fb}}\left(\mathrm{CH}_{3} \mathrm{SO}_{3}{ }^{-}\right)<E_{\mathrm{fb}}\left(\mathrm{HSO}_{4}{ }^{-}\right)<E_{\mathrm{fb}}\left(\mathrm{ClO}_{4}{ }^{-}\right)$in ACN and similarly was $E_{\mathrm{fb}}\left(\mathrm{Cl}^{-}\right)<E_{\mathrm{fb}}\left(\mathrm{CH}_{3} \mathrm{SO}_{3}{ }^{-}\right)<E_{\mathrm{fb}}\left(\mathrm{HSO}_{4}{ }^{-}\right)<E_{\mathrm{fb}}\left(\mathrm{ClO}_{4}{ }^{-}\right)$ in PC. These relationships were conserved for results obtained over a three decade range of frequencies, and were reproduced by two independent sets of measurements.

\section{Regenerative photoelectrochemistry}

The $\mathrm{B}_{10} \mathrm{Br}_{10}{ }^{-/ 2-}$ redox couple was produced by mixing decabromo-closo-decaborate $\left(\mathrm{B}_{10} \mathrm{Br}_{10}{ }^{2-}\right)$ and bis(methanesulfonyl) peroxide $\left[\left(\mathrm{CH}_{3} \mathrm{SO}_{3}\right)_{2}\right]$ in dry, air-saturated ACN. Fig. 4 shows the UV-visible absorption spectrum of $\mathrm{B}_{10} \mathrm{Br}_{10}{ }^{-}$, whose blackbrown color $^{31}$ appeared within minutes of the reaction, and subsequently persisted for several weeks. In contact with the

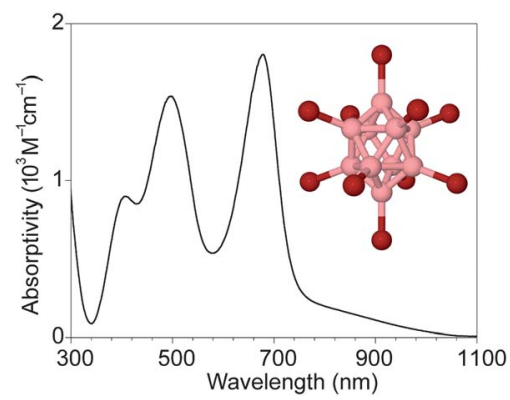

Fig. 4 UV-visible spectrum of the radical anion $\mathrm{B}_{10} \mathrm{Br}_{10}{ }^{-}$, generated in ACN by oxidizing $\mathrm{B}_{10} \mathrm{Br}_{10}{ }^{2-}$ with $\left(\mathrm{CH}_{3} \mathrm{SO}_{3}\right)_{2}$. The calculated absorptivity values are approximate. Inset: a ball-and-stick model of $\mathrm{B}_{10} \mathrm{Br}_{10^{-12-}}$, where the pink balls stand for B and the brown balls for $\mathrm{Br}$.

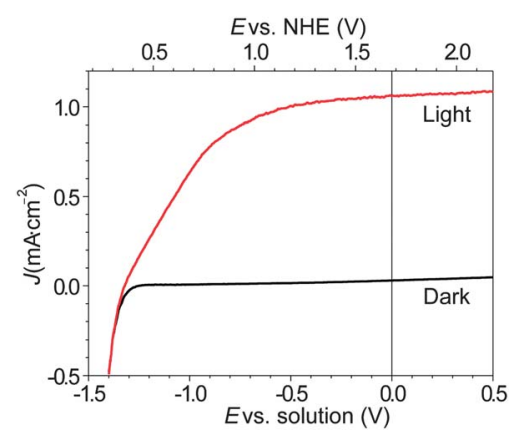

Fig. 5 Voltammograms of a $\mathrm{WO}_{3} / \mathrm{W}$ photoanode in contact with $1 \mathrm{mM}$ $\mathrm{B}_{10} \mathrm{Br}_{10}{ }^{-12-}$ and $0.50 \mathrm{M} \mathrm{TBASO}_{3} \mathrm{CH}_{3}$ in $\mathrm{ACN}$, in the dark (black) or under $100 \mathrm{~mW} \mathrm{~cm}^{-2}$ of AM 1.5G illumination (red). These $J-E$ data were referenced to $\mathrm{NHE}$, as well as to a Pt wire that probed $E\left(\mathrm{~B}_{10} \mathrm{Br}_{10}{ }^{-12-}\right)$ as the solution potential. 
$\mathrm{B}_{10} \mathrm{Br}_{10}{ }^{-/ 2-}$ redox couple in $\mathrm{ACN}$, the $\mathrm{WO}_{3} / \mathrm{FTO}$ photoanode generated negligible photocurrent density. No damage to the $\mathrm{WO}_{3}$ film was observable, and the $J-E$ behavior of the $\mathrm{WO}_{3} / \mathrm{FTO}$ photoanode fully recovered when the photoanode was rinsed with acetone and tested in an electrolyte that did not contain any deliberately added $\mathrm{B}_{10} \mathrm{Br}_{10}{ }^{-/ 2-}$. In contrast, Fig. 5 shows the photoelectrochemical performance of the $\mathrm{WO}_{3} / \mathrm{W}$ photoanode in contact with $1 \mathrm{mM} \mathrm{B}_{10} \mathrm{Br}_{10}{ }^{-/ 2-}$ and $0.50 \mathrm{M} \mathrm{TBASO}_{3} \mathrm{CH}_{3}$ in ACN, whose solution potential was determined by a Pt wire to be $1.68 \mathrm{~V} v s$. NHE. In the dark, the $\mathrm{WO}_{3} / \mathrm{W}$ photoanode produced very small $\left(<0.05 \mathrm{~mA} \mathrm{~cm} \mathrm{~cm}^{-2}\right)$ anodic current densities, but exhibited significant cathodic current densities at potentials $<\sim 0.4 \mathrm{~V}$ vs. NHE. Under $100 \mathrm{~mW} \mathrm{~cm} \mathrm{~cm}^{-2}$ of simulated AM 1.5G illumination, the cell produced a short-circuit photocurrent density, $J_{\mathrm{sc}}=1.06 \mathrm{~mA} \mathrm{~cm}^{-2}$, an open-circuit voltage, $V_{\text {oc }}=1.32 \mathrm{~V}$, a fill factor of 0.50 , and a photoelectrode energyconversion efficiency of $\eta=0.71 \%$ (which included losses due to light extinction by $\mathrm{B}_{10} \mathrm{Br}_{10}{ }^{-}$and to solution resistances).

\section{Discussion}

\section{Porous $\mathrm{WO}_{3}$ photoanodes}

$\mathrm{WO}_{3}$ photoanodes have been fabricated by electrodeposition from peroxytungstic acid, and have been characterized by X-ray diffraction and scanning electron microscopy. ${ }^{12,13,32}$ In previous preparations of peroxytungstic acid, $\mathrm{W}$ metal was reacted with concentrated $\mathrm{H}_{2} \mathrm{O}_{2}(\mathrm{aq})$ and then the excess $\mathrm{H}_{2} \mathrm{O}_{2}$ was decomposed. However, in the peroxytungstic acid thus obtained, the concentration of the residual free $\mathrm{H}_{2} \mathrm{O}_{2}$, which has been found ${ }^{12}$ to be critical for the electrodeposition, is difficult to reproduce precisely. In this work, peroxytungstic acid was prepared within minutes by proton exchange of $\mathrm{Na}_{2} \mathrm{WO}_{4}(\mathrm{aq})$ in the presence of a stoichiometric amount of $\mathrm{H}_{2} \mathrm{O}_{2}$, and the peroxytungstic acid was consumed promptly in the subsequent electrodeposition. This procedure provided excellent reproducibility in the resulting peroxytungstic acid, as well as in the photoelectrochemical performance of the $\mathrm{WO}_{3}$ photoanodes.

The (photo)electrochemical experiments described herein suggest that the $\mathrm{WO}_{3}$ films, prepared by electrodeposition and annealing, were porous across the entire film thickness. For the $\mathrm{WO}_{3} /$ FTO photoanode, the electrolyte percolated into the $\mathrm{WO}_{3}$ film and contacted the conducting FTO substrate. Thus the $\mathrm{WO}_{3} /$ FTO photoanode oxidized $1.0 \mathrm{M} \mathrm{HCl}(\mathrm{aq})$ in the dark at $E \sim 1.6 \mathrm{~V} v s$. NHE, a potential in the band gap region of $\mathrm{WO}_{3}$. Nevertheless, the $\mathrm{WO}_{3} / \mathrm{FTO}$ photoanode produced substantial photocurrent densities in contact with $1.0 \mathrm{M} \mathrm{HCl}(\mathrm{aq})$, because the $\mathrm{Cl}^{-} / \mathrm{Cl}_{2}$ redox couple could not be rapidly regenerated by electrons in the FTO substrate. In contrast, when contacted with the electrochemically reversible $\mathrm{B}_{10} \mathrm{Br}_{10}{ }^{-/ 2-}$ redox couple, the $\mathrm{WO}_{3} /$ FTO photoanode produced a nearly complete loss of photocurrent, which can be explained by severe current shunting at the FTO/electrolyte interface. The minimal current shunting observed for the same electrolyte and redox couple conditions for the $\mathrm{WO}_{3} / \mathrm{W}$ electrode is consistent with expectations for the presence of a compact oxide layer on the $\mathrm{W}$ surfaces that prevented direct contact between the $\mathrm{W}$ and the $\mathrm{Cl}^{-}$or $\mathrm{B}_{10} \mathrm{Br}_{10}^{-}$in the electrolyte.

\section{Proton intercalation of $\mathrm{WO}_{3}$ in aqueous acids}

The capacitive dark currents (Fig. S2 $\dagger$ ) and electrochromism of the $\mathrm{WO}_{3}$ photoanodes in aqueous acids are consistent with the electrochemical intercalation of protons into $\mathrm{WO}_{3}$ as per eqn (2):

$$
\begin{aligned}
& \mathrm{WO}_{3}+x \mathrm{H}^{+}(\mathrm{aq})+x \mathrm{e}^{-} \leftrightarrow \\
& \mathrm{H}_{x} \mathrm{WO}_{3} \equiv x \mathrm{H}^{+}\left(\text {in } \mathrm{WO}_{3}\right)+x \mathrm{e}^{-}\left(\text {in } \mathrm{WO}_{3}\right)(2)
\end{aligned}
$$

This reaction has a standard electrode potential of $0.29 \mathrm{~V} v s$. NHE for $x=1 .^{33}$ The formation of $\mathrm{H}_{x} \mathrm{WO}_{3}$ is consistent with the blue color observed for the cathodically charged $\mathrm{WO}_{3}$ films, and for the internal stress that accumulated within the $\mathrm{WO}_{3}$ film at large negative potentials.

Eqn (2) also provides a consistent explanation for the differential capacitance data in Fig. 3A and other data reported previously, ${ }^{34}$ which indicate that the $E_{\mathrm{fb}}$ value for $\mathrm{WO}_{3}$ in contact with a variety of $1.0 \mathrm{M}$ aqueous strong acids was nearly independent of the electrolyte. At $E \leq 0.4 \mathrm{~V} v s$. NHE, $\mathrm{H}_{x} \mathrm{WO}_{3}$ with $x$ calculated to be $>0.1$ is degenerately doped and thus not photoactive. For $E=0.4-1.2 \mathrm{~V}$ vs. NHE, the $J-E$ data in Fig. $1 \mathrm{~A}$ exhibited values of $E_{\text {on }}$ that were a function of the anion. In aqueous strong acids, $\mathrm{WO}_{3}$ photoanodes have been shown to preferentially oxidize the acid anions relative to the oxidation of water. ${ }^{11-13}$ The anion-dependent $E_{\text {on }}$ values have therefore been suggested to reflect a competition between the different rates of charge recombination and of interfacial electron transfer in each system. ${ }^{35}$ In this framework, $\mathrm{Cl}^{-}(\mathrm{aq})$ would have the highest ratio of charge transfer relative to recombination, and therefore produces significant photocurrent densities at the most negative $E_{\text {on }}$ value of all of the anions studied herein.

\section{$\mathrm{WO}_{3} /$ electrolyte interfaces in aprotic solvents}

In ACN or PC, electrochromism of the $\mathrm{WO}_{3}$ film was not observed. The $J-E$ data of Fig. $1 \mathrm{~B}$ and $\mathrm{C}$ indicate that in these solvents, the differences between the onset and inflection potentials were almost constant, with a value of $\sim 0.7 \mathrm{~V}$. Photoelectrochemical oxidation of the electrolyte anions presumably involves radical intermediates $\left(\mathrm{Cl}, \mathrm{CH}_{3} \mathrm{SO}_{3}, \mathrm{HSO}_{4}\right.$; and $\mathrm{ClO}_{4}$ ) that are adsorbed to the $\mathrm{WO}_{3}$ surface via a labile $\mathrm{O}-\mathrm{Cl}$ or $\mathrm{O}-\mathrm{O}$ bond, prior to the formation of more stable oxidation products such as $\mathrm{Cl}_{2}(\mathrm{~g}),\left(\mathrm{CH}_{3} \mathrm{SO}_{3}\right)_{2}$, and $\mathrm{S}_{2} \mathrm{O}_{8}{ }^{2-}$ (the final oxidation product of $\mathrm{ClO}_{4}{ }^{-}$was unidentified). The surface potential of the $\mathrm{WO}_{3}$ photoanode can therefore be significantly influenced in aprotic solvents by the adsorbed radical species, in which interfacial electric dipoles with partial positive charges on the electrolyte side and partial negative charges on the $\mathrm{WO}_{3}$ side can offset a portion of the applied anodic potential. This mechanistic picture is strongly supported by the systematic shift in $E_{\mathrm{fb}}$ for $\mathrm{WO}_{3}$ in contact with the various electrolytes (Fig. 3B and C), and also agrees with current knowledge of the surface modification of Si photoelectrodes. ${ }^{23}$

The presence of surface-attached radicals is also consistent with the values of $J_{\mathrm{ph}}$ and $\Phi_{\text {int }}$ observed for $\mathrm{WO}_{3}$ photoanodes in contact with $0.50 \mathrm{M} \mathrm{TBAClO}_{4}$ in PC. $\Phi_{\text {int }}$ values exceeding unity indicate that more than one conduction-band electron was 
generated by an absorbed photon. Current doubling takes place when an electrode reaction involves reactive intermediates, usually free radicals, that inject majority carriers (i.e., electrons for an n-type photoanode and holes for a p-type photocathode) into the electrode, in addition to photogenerated carriers. ${ }^{\mathbf{4}, 36}$ One explanation of the data is that the radical intermediate $\mathrm{ClO}_{4}$ was not reducing enough to cause current doubling in water and ACN, but could oxidize an adjacent PC molecule to a PC radical:

$$
\mathrm{ClO}_{4}{ }^{\circ}+\mathrm{O}_{\mathrm{O}}^{\mathrm{O}} \mathrm{Y} \mathrm{HClO}_{4}+\mathrm{OF}_{\mathrm{O}}^{\mathrm{O}}
$$

A similar reaction between $\mathrm{PC}$ and the hydroxyl radical is known, ${ }^{37}$ and the standard reduction potential of $\mathrm{OH}^{-}(2.85 \mathrm{~V})^{38}$ is close to that of $\mathrm{ClO}_{4}(2.75 \mathrm{~V}$ vs. NHE $) ;^{39}$ many other organic oxygenates have also been $\operatorname{shown}^{\mathbf{4 , 4 0}}$ to be responsible for current doubling. The newly formed PC radical would then be able to inject an electron to the conduction band of $\mathrm{WO}_{3}$ before diffusing away from the electrode surface, leading to $\Phi_{\text {int }}>1$. The values of $\Phi_{\text {int }}$ shown in Table 1 for other electrolytes $(0.50 \mathrm{M}$ $\mathrm{Cl}^{-}, \mathrm{CH}_{3} \mathrm{SO}_{3}{ }^{-}$, or $\mathrm{HSO}_{4}{ }^{-}$in $\mathrm{PC}$ ) are well below unity, which is consistent with the expectation that their radical forms $(\mathrm{Cl}$, $\mathrm{CH}_{3} \mathrm{SO}_{3}$, or $\mathrm{HSO}_{4}$ ) are more subject to dimerization than to reaction with $\mathrm{PC}$, thereby terminating current doubling. These results clearly demonstrate that at the $\mathrm{WO}_{3}$ /electrolyte interface, discharging of the electrode anion is the predominant process, whereas oxidation of the solvent is only a secondary reaction.

\section{Regeneration of photoanodic products}

In aqueous acids, $E_{\text {on }}$ is limited by proton intercalation in $\mathrm{WO}_{3}$, and the photoanodic product is ultimately $\mathrm{O}_{2}(\mathrm{~g})$. Compared with water, ACN possesses a much wider potential window, and allows for more negative values of $E_{\mathrm{on}}$ for $\mathrm{WO}_{3}$ in contact with $\mathrm{Cl}^{-}, \mathrm{CH}_{3} \mathrm{SO}_{3}{ }^{-}$, or $\mathrm{HSO}_{4}{ }^{-}$(Fig. $1 \mathrm{~A}$ and B). The photoanodic products of the latter two anions are powerful oxidants: $E^{0}\left(\mathrm{HSO}_{4}{ }^{-} / \mathrm{S}_{2} \mathrm{O}_{8}{ }^{2-}\right)=2.12 \mathrm{~V}$ vs. $\mathrm{NHE}{ }^{38}$ whereas the value of $E^{0}\left(\mathrm{CH}_{3} \mathrm{SO}_{3}{ }^{-} /\left(\mathrm{CH}_{3} \mathrm{SO}_{3}\right)_{2}\right)$ has so far been unreported but is predicted to be $<2.12 \mathrm{~V}$. However, these two-electron redox couples are not reduced at a reasonable overpotential on Pt surfaces. For example, the cathodic reduction of $\mathrm{S}_{2} \mathrm{O}_{8}{ }^{2-}$ (aq) is reported ${ }^{41}$ to occur at $\sim 0.6 \mathrm{~V} v s$. NHE, a potential much more negative than $E^{0}\left(\mathrm{HSO}_{4}{ }^{-} / \mathrm{S}_{2} \mathrm{O}_{8}{ }^{2-}\right)$.

In this work, $\left(\mathrm{CH}_{3} \mathrm{SO}_{3}\right)_{2}$ was activated by decabromo-closodecaborate $\left(\mathrm{B}_{10} \mathrm{Br}_{10}{ }^{2-}\right)$, a spheroid-shaped anion that is depicted in the inset of Fig. 4:

$$
\left(\mathrm{CH}_{3} \mathrm{SO}_{3}\right)_{2}+2 \mathrm{~B}_{10} \mathrm{Br}_{10}{ }^{2-} \rightarrow 2 \mathrm{CH}_{3} \mathrm{SO}_{3}^{-}+2 \mathrm{~B}_{10} \mathrm{Br}_{10}^{-}
$$

$\mathrm{B}_{10} \mathrm{Br}_{10}{ }^{2-}$ exhibits high chemical stability ${ }^{26}$ and a reversible, one-electron redox system with a formal oxidation potential of $1.78 \mathrm{~V} v s$. NHE. ${ }^{31}$ The Nernst potential of the solution as probed by a Pt wire was observed to be $1.68 \mathrm{~V} v s$. NHE, therefore providing an opportunity to produce large barrier heights, and correspondingly large open-circuit voltages from regenerative photoelectrochemical cells that use this redox system in contact with $\mathrm{WO}_{3}$ photoanodes.
When $1 \mathrm{mM} \mathrm{B}_{10} \mathrm{Br}_{10}{ }^{-/ 2-}$ was introduced to $0.50 \mathrm{M}$ TBA$\mathrm{SO}_{3} \mathrm{CH}_{3}$ in ACN, the $\mathrm{WO}_{3} / \mathrm{W}$ photoanode exhibited $E_{\text {oc }}=0.36 \mathrm{~V}$ $v s$. NHE, corresponding to an open-circuit voltage $\left(V_{\mathrm{oc}}\right)$ of $1.32 \mathrm{~V}$. This value is by far in excess of the nominal $V_{\mathrm{oc}}$ that $\mathrm{WO}_{3}$ can generate in aqueous electrolytes $(\leq 0.8 \mathrm{~V})$. Thus, the $\mathrm{B}_{10} \mathrm{Br}_{10}^{-/ 2-}$ redox system provided an approach to convert the chemical energy that was stored in $\left(\mathrm{CH}_{3} \mathrm{SO}_{3}\right)_{2}$ into a solution potential that could readily generate electrical power, at the expense of a loss in potential of $0.2-0.3 \mathrm{~V}$. A drawback to the use of this redox couple is that the oxidized species, $\mathrm{B}_{10} \mathrm{Br}_{10}{ }^{-}$, absorbed a portion of the incoming light, and contributed to a reduction of $J_{\mathrm{ph}}$ from $\sim 1.4 \mathrm{~mA} \mathrm{~cm}^{-2}$ in Fig. 1B to $1.06 \mathrm{~mA} \mathrm{~cm}^{-2}$ (in Fig. 5). Such optical losses can be minimized in cell configurations that utilize a thin layer of electrolyte, ${ }^{\mathbf{4 2}}$ and/or deeply integrated electrolyte/electrode microstructures. ${ }^{43}$

\section{Conclusions}

In contact with $1.0 \mathrm{M}$ aqueous strong acids, at $E=0.4-1.2 \mathrm{~V} v s$. NHE, charge recombination competed with anion oxidation at the $\mathrm{WO}_{3}$ /electrolyte interfaces, leading to an anion-dependent onset of photoanodic current, although the flat-band potential stayed nearly constant. In aprotic solvents, both the flat-band potential and the onset potential of the photoanodic current shifted as the anion was changed, but the overall profile of the $J-E$ data remained relatively constant. $\mathrm{WO}_{3}$ photoanodes in contact with $0.50 \mathrm{M} \mathrm{TBAClO}_{4}$ in PC exhibited $\Phi_{\text {int }}$ values greater than unity at 300-390 nm, owing to current doubling. When $\mathrm{WO}_{3}$ was used as a photoanode in a regenerative photoelectrochemical cell configuration, the reversible, high-potential redox system $1 \mathrm{mM} \mathrm{B}_{10} \mathrm{Br}_{10}{ }^{-/ 2-}$ with $0.50 \mathrm{M}$ $\mathrm{TBASO}_{3} \mathrm{CH}_{3}$ in ACN produced a solution potential of $\sim 1.7 \mathrm{~V} v \mathrm{~s}$. $\mathrm{NHE}$, and an open-circuit voltage of $1.32 \mathrm{~V}$ under $100 \mathrm{~mW} \mathrm{~cm}^{-2}$ of simulated AM 1.5G illumination.

\section{Acknowledgements}

We acknowledge the National Science Foundation (NSF) Powering the Planet Center for Chemical Innovation (CCI-Solar), Grants CHE-0802907 and CHE-0947829, and the Molecular Materials Research Center of the Beckman Institute at the California Institute of Technology, for support. QM acknowledges Dr Elizabeth A. Santori for assistance with the spectral response experiments, and the NSF for support as a CCI-Solar Postdoctoral Fellow.

\section{References}

1 G. Hodes, D. Cahen and J. Manassen, Nature, 1976, 260, 312313.

2 W. Erbs, J. Desilvestro, E. Borgarello and M. Grätzel, J. Phys. Chem., 1984, 88, 4001-4006.

3 K. Sayama, R. Yoshida, H. Kusama, K. Okabe, Y. Abe and H. Arakawa, Chem. Phys. Lett., 1997, 277, 387-391.

4 C. Santato, M. Ulmann and J. Augustynski, J. Phys. Chem. B, 2001, 105, 936-940.

5 A. Valdes and G. J. Kroes, J. Chem. Phys., 2009, 130, 114701. 
6 R. Liu, Y. J. Lin, L. Y. Chou, S. W. Sheehan, W. S. He, F. Zhang, H. J. M. Hou and D. W. Wang, Angew. Chem., Int. Ed., 2011, 50, 499-502.

7 F. M. Pesci, A. J. Cowan, B. D. Alexander, J. R. Durrant and D. R. Klug, J. Phys. Chem. Lett., 2011, 2, 1900-1903.

8 J. Brillet, J. H. Yum, M. Cornuz, T. Hisatomi, R. Solarska, J. Augustynski, M. Grätzel and K. Sivula, Nat. Photonics, 2012, 6, 823-827.

9 X. Liu, F. Y. Wang and Q. Wang, Phys. Chem. Chem. Phys., 2012, 14, 7894-7911.

10 S. S. K. Ma, K. Maeda, R. Abe and K. Domen, Energy Environ. Sci., 2012, 5, 8390-8397.

11 J. Augustynski, R. Solarska, H. Hagemann and C. Santato, Proc. SPIE, 2006, 6340, 63400J.

12 Q. X. Mi, A. Zhanaidarova, B. S. Brunschwig, H. B. Gray and N. S. Lewis, Energy Environ. Sci., 2012, 5, 5694-5700.

13 J. C. Hill and K. S. Choi, J. Phys. Chem. C, 2012, 116, 76127620.

14 R. Solarska, R. Jurczakowski and J. Augustynski, Nanoscale, 2012, 4, 1553-1556.

15 E. A. Santori, J. R. Maiolo, M. J. Bierman, N. C. Strandwitz, M. D. Kelzenberg, B. S. Brunschwig, H. A. Atwater and N. S. Lewis, Energy Environ. Sci., 2012, 5, 6867-6871.

16 N. C. Strandwitz, D. B. Turner-Evans, A. C. Tamboli, C. T. Chen, H. A. Atwater and N. S. Lewis, Adv. Energy Mater., 2012, 2, 1109-1116.

17 S. N. Frank and A. J. Bard, J. Am. Chem. Soc., 1975, 97, 74277433.

18 P. A. Kohl and A. J. Bard, J. Am. Chem. Soc., 1977, 99, 75317539.

19 D. E. Scaife, Sol. Energy, 1980, 25, 41-54.

20 M. T. Nenadovic, T. Rajh, O. I. Micic and A. J. Nozik, J. Phys. Chem., 1984, 88, 5827-5830.

21 F. P. Koffyberg, K. Dwight and A. Wold, Solid State Commun., 1979, 30, 433-437.

22 N. S. Lewis, J. Electrochem. Soc., 1984, 131, 2496-2503.

23 R. L. Grimm, M. J. Bierman, L. E. O'Leary, N. C. Strandwitz, B. S. Brunschwig and N. S. Lewis, J. Phys. Chem. C, 2012, 116, 23569-23576.
24 C. J. Myall and D. Pletcher, J. Chem. Soc., Perkin Trans. 1, 1975, 953-955.

25 M. F. Hawthone and R. N. Pilling, Inorg. Synth., 1967, 9, 16-19.

26 W. H. Knoth, H. C. Miller, J. C. Sauer, J. H. Balthis, Y. T. Chia and E. L. Muetterties, Inorg. Chem., 1964, 3, 159-167.

27 C. G. Zoski, Handbook of electrochemistry, Elsevier, Amsterdam, Boston, 2007.

$28 \mathrm{~K}$. Izutsu, Electrochemistry in nonaqueous solutions, WileyVCH, Weinheim, Germany, 2002.

29 N. G. Connelly and W. E. Geiger, Chem. Rev., 1996, 96, 877910.

30 J. A. Davies, C. T. Eagle, D. E. Otis and U. Venkataraman, Organometallics, 1989, 8, 1080-1088.

31 W. Einholz, K. Vaas and C. Wieloch, Z. Anorg. Allg. Chem., 2002, 628, 258-268.

32 E. A. Meulenkamp, J. Electrochem. Soc., 1997, 144, 16641671.

33 M. L. Hitchman, J. Electroanal. Chem., 1977, 85, 135-144.

34 P. Lemasson, A. M. Baticle and P. Vennereau, Surf. Sci., 1976, 59, 177-194.

35 N. Vlachopoulos, P. Liska, J. Augustynski and M. Grätzel, J. Am. Chem. Soc., 1988, 110, 1216-1220.

36 R. Memming, J. Electrochem. Soc., 1969, 116, 785-790.

37 E. A. Shaede and M. C. R. Symons, Can. J. Chem., 1973, 51, 2492-2496.

38 CRC handbook of chemistry and physics, ed. W. M. Haynes, CRC Press, Boca Raton, FL, 91st edn, 2010.

39 I. V. Shimonis, Elektrokhimiya, 1973, 9, 1787-1789.

40 D. V. Esposito, R. V. Forest, Y. C. Chang, N. Gaillard, B. E. McCandless, S. Y. Hou, K. H. Lee, R. W. Birkmire and J. G. G. Chen, Energy Environ. Sci., 2012, 5, 90919099.

41 H. S. White and A. J. Bard, J. Am. Chem. Soc., 1982, 104, 68916895.

42 J. F. Gibbons, G. W. Cogan, C. M. Gronet, N. S. Lewis, US Pat. no. 4764439A, 1988.

43 C. Xiang, A. C. Meng and N. S. Lewis, Proc. Natl. Acad. Sci. U. S. A., 2012, 109, 15622-15627. 